\title{
ANALISIS KESULITAN BELAJAR ANAK DISGRAFIA PADA MATA PELAJARAN BAHASA INDONESIA DI KELAS IV SDN KARANG TENGAH 5 KOTA TANGERANG
}

\author{
${ }^{1}$ Lusiana Della Paramita*, ${ }^{2}$ Septy Nurfadhillah, ${ }^{3}$ Sa'odah \\ 1,2,3 Program Studi Pendidikan Guru Sekolah Dasar, Fakultas Ilmu Pendidikan dan Keguruan, \\ Universitas Muhammadiyah Tangerang \\ 1ㅣㄴianadella@gmail.com* ${ }^{2}$ nurfadhillahsepty@gmail.com,
}

\begin{abstract}
ABSTRAK
Penelitian ini bertujuan untuk mengetahui kesulitan belajar anak disgrafia pada mata pelajaran bahasa indonesia di kelas IV SDN Karang Tengah 5 Kota Tangerang. Penelitian ini merupakan penelitian kualitatif dengan metode penelitian studi kasus. Subjek dalam penelitian ini yaitu guru kelas IV, siswa dan orang tua siswa. Pengumpulan data diambil melalui observasi, wawancara dan studi dokumen. Penulis berperan sebagai pewarta atau pewawancara langsung untuk mendapatkan data melalui guru kelas IV dan orang tua siswa. Hasil penelitian menunjukkan bahwa terdapat dua siswa yang mengalami kesulitan belajar menulis atau disgrafia, yaitu pada saat belajar bahasa indonesia mereka berdua tidak dapat menulis karangan dengan baik dan benar, dalam tulisannya terdapat huruf yang terbalik, penggunaan huruf besar dengan huruf kecil masih tercampur dan penggunaan ejaan yang tidak tepat karena kedua siswa sering menambahkan atau mengurangi huruf sehingga membuat tulisannya sulit terbaca.
\end{abstract}

Kata kunci: Kesulitan Belajar, Disgrafia, Pembelajaran Bahasa Indonesia

\begin{abstract}
This study aims to determine the learning difficulties of dysgraphia children in Indonesian subjects in grade IV SDN Karang Tengah 5 Tangerang City. This research is qualitative research with case study research method. The subjects in this study were fourth grade teacher, students, and parents. Data collection was taken through observation, interviews, and document studies. The author act as a reporter or direct interviewer to obtain data through fourth grade teacher and students' parents. The results showed that there were two students who had difficulty learning to write or dysgraphia, namely when learning Indonesian they both could not write essays properly and correctly, in their writings there were reversed letters, the use of uppercase letters and lowercase letters was still mixed and the use of spelling which is not appropriate because the two students are often add or substract letters that makes the writing is difficult to read.
\end{abstract}

Keywords: Difficulty Learning, Dysgraphia, Indonesian Lesson

\section{PENDAHULUAN}

Pendidikan merupakan hal yang penting bagi setiap manusia. Sejak dari dalam kandungan sampai tua kemudian meninggal, manusia memperoleh pendidikan dari keluarga, masyarakat maupun lingkungannya. Pendidikan harus didapatkan oleh setiap manusia karena pendidikan berperan penting dalam membentuk generasi mendatang.

Bagi masyarakat indonesia sendiri pendidikan adalah hal yang wajib didapatkan. Sebagaimana tercantum dalam Undang-
Undang Dasar (UUD) 1945 pasal 31 ayat (1), dimana setiap warga negara Indonesia berhak memperoleh pendidikan yang layak. Dengan demikian baik si kaya, si miskin maupun orang dengan latar belakang apapun berhak mendapatkan pendidikan (tanpa terkecuali).

Dengan pendidikan kita mengalami sebuah perubahan. Perubahan dari tidak tahu menjadi tahu, dari tidak bisa menjadi bisa. Perubahan tersebut di dapat dari sebuah proses yang sering disebut dengan belajar. Dalam aktivitas belajar terkadang tidak 


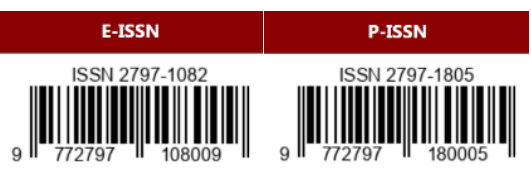

selamanya berjalan lancar, karena setiap siswa memiliki karakteristik dan kemampuan yang berbeda-beda. Sehingga masih terdapat siswa yang mengalami kesulitan belajar, hal ini menjadi hambatan dalam proses pembelajaran karena mereka tidak dapat mencapai tujuan pembelajaran yang telah ditentukan. Salah satu kesulitan belajar yang sering dialami oleh siswa ialah kesulitan belajar menulis atau biasa disebut disgrafia. Anak yang mengami disgrafia biasanya cenderung memiliki tulisan yang sulit terbaca, dikarenakan mereka menulis tidak sebagaimana mestinya. Padahal, menulis adalah salah satu aspek keterampilan berbahasa yang sangat penting dalam pembelajaran karena keberhasilan siswa dalam mengikuti kegiatan pembelajaran di sekolah banyak ditentukan dari kemampuannya dalam menulis.

Berdasarkan observasi dan wawancara awal sebelum penelitian yang peneliti lakukan di kelas IV SDN Karang Tengah 5 Kota Tangerang dari jumlah siswa 20 orang, peneliti menemukan terdapat 2 siswa yang mengalami kesulitan belajar menulis atau disgrafia. Kedua anak tersebut menunjukkan ciri-ciri dari kesulitan belajar disgrafia, yakni salah satu diantara anak tersebut masih sulit dalam memegang pensil atau pulpen. Kemudian, anak tesebut juga ketika menulis pandangan matanya terlalu dekat dengan buku sehingga saat sedang menulis kepalanya selalu tertunduk. Selain itu ciri lain yang tampak dari mereka berdua ialah, dari bentuk tulisannya yang tidak konsisten antara huruf kapital dengan huruf kecil masih tercampur, lalu ukuran dan bentuk huruf pada tulisan mereka tidak proposional. Dari tulisan mereka berdua juga ditemukan huruf-huruf yang terbalik misal huruf i menjadi $\mathrm{y}$, kemudian huruf $\mathrm{m}$ menjadi $\mathrm{n}$ dan seterusnya. Mereka berdua juga sering kali menambahkan huruf atau mengurangi huruf pada tulisannya, hal ini juga terjadi ketika mereka hanya diminta untuk menyalin tulisan yang sudah ada sehingga membuat tulisan dari mereka sulit untuk dibaca. Tidak hanya itu, mereka berdua juga terlihat sangat sulit ketika diminta untuk mengkomunikasikan ide, pengetahuan atau pemahamannya lewat tulisan.

Berdasarkan masalah yang telah dikemukakan twersebut, peneliti terdorong untuk melakukan penelitian secara mendalam guna mendapatkan jawaban atas masalahmasalah terkait usaha dan upaya guru dalam membantu siswa yang mengalami kesulitan belajar disgrafia dalam mata pelajaran Bahasa Indonesia agar tujuan pembelajaran dapat tercapai. Oleh karena itu, peneliti akan melakukan penelitian dengan judul "Analisis Kesulitan Belajar Anak Disgrafia Pada Mata Pelajaran Bahasa Indonnesia Di Kelas IV SDN Karang Tengah 5 Kota Tangerang".

\section{LANDASAN TEORI}

Kesulitan Belajar

Kegiatan belajar mengajar di sekolah tidak selamanya dapat berjalan dengan lancar, dalam prosesnya terkadang masih ditemui berbagai hambatan salah satunya adalah kesulitan belajar. Kesulitan belajar merupakan masalah umum yang sering terjadi hampir disetiap kegiatan proses belajar mengajar dan menjadi hambatan utama dalam mencapai tujuan belajar.

Kesulitan belajar atau dalam bahasa inggris disebut dengan learning disability atau learning difficulty merupakan suatu keadaan yang membuat individu merasa kesulitan dalam kegiatan belajar (Maryani, dkk, 2018, h. 23). Hal serupa juga disampaikan oleh Urbayatun (2019), "Kesulitan belajar merupakan suatu hambatan atau gangguan 
yang dialami oleh anak dalam kegiatan belajar sehingga menghambat tercapainya suatu tujuan belajar dan menghambat meningkatnya taraf belajar seseorang" (h. 7). Dari kedua pendapat tersebut dapat dipahami bahwa kesulitan belajar merupakan suatu keadaan yang menjadi hambatan dan gangguan yang terjadi pada anak sehingga menyebabkan proses belajar tidak berjalan lancar.

Gejala kesulitan belajar dapat diketahui dengan membuat kriteria-kriteria tertentu terhadap setiap individu yang diduga mengalami kesulitan belajar, hal tersebut bertujuan untuk menentukan batas individu dalam mengalami kesulitan belajar. Berdasarkan hal tersebut, menurut kemendikbud dan direktorat jendral pendidikan tinggi (1994) kriteria kesulitan belajar dapat ditentukan sebagai berikut (Rofiqi dan Rosyid, 2020, h. 25-29):

1. Tingkat pencapaian tujuan

Murid yang mendapatkan hambatan dalam mencapai tujuan atau murid yang tidak dapat mencapai tujuan diperkirakan mengalami kesulitan belajar.

2. Perbandingan antara potensi dengan prestasi.

Murid yang mendapatkan kesulitan belajar jika terdapat perbedaana yang besar antara potensi dengan prestasi.

3. Kedudukan dalam kelompok.

Murid diperkirakan mengalami kesulitan belajar jika menduduki urutan paling bawah dalam kelompoknya.

4. Tingkah laku yang nampak.

Murid yang tidak berhasil dalam belajar akan menunjukkan pola tingkah laku yang menyimpang.

\section{Disgrafia}

Dalam belajar setiap anak memilki kemampuan yang berbeda-beda. Mereka tidaklah sama antara satu dengan yang lainnya, terdapat anak yang ketika belajar dia cepat paham dan mengerti apa yang disampaikan oleh guru. namun, ada pula anak yang ketika belajar mereka mengalami kesulitan. Salah satu kesulitan belajar yang sering terjadi pada siswa sekolah dasar salah satunya adalah kesulitan belajar menulis atau disgrafia.

Menurut Puspitasari dan Rahmawati (2018), "Disgrafia merupakan kesulitan khusus dengan kondisi anak tidak mampu, menuliskan atau mengekspresikan pikirannya ke dalam bentuk tulisan" (h. 67). Maksud dari kutipan di atas disgrafia adalah kondisi dimana anak tidak dapat mengekspresikan pikiran yang ia milki kedalam sebuah tulisan, anak merasa sulit dan tidak mampu.

Terdapat beberapa ciri-ciri yang menunjukkan jika anak mengalami disgrafia, seperti yang dikemukakan oleh Aphroditta (2013, h. 60) ada beberapa ciri khusus anak dengan gangguan disgrafia, diantaranya adalah sebagai berikut:

1. Terdapat ketidak konsitenan bentuk huruf dalam tulisannya.

2. Saat menulis, penggunaan huruf kapital dan huruf kecil masih tercampur.

3. Ukuran dan bentuk huruf dalam tulisannya tidak proporsional.

4. Anak tampak harus berusaha keras saat mengkomunikasikan suatu ide, pengetahuan, atau pemahaman lewat tulisan.

5. Sulit memegang bolpoin maupun pensil dengan mantap. Caranya memegang alat tulis sering terlalu dekat, bahkan hampir menempel dengan kertas.

6. Berbicara pada diri sendiri ketika sedang menulis, atau malah terlalu memperhatikan tangan yang dipakai untuk menulis. 


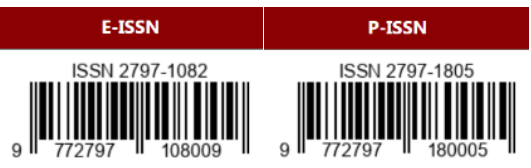

Volume 2 Nomor 1 (Desember 2021 - Februari 2022)

7. Cara menulis tidak konsisten, tidak mengikuti alur garis yang tepat dan proporsional.

8. Tetap mengalami kesulitan meskipun hanya diminta menyalin contoh tulisan yang sudah ada.

\section{METODE PENELITIAN}

Penelitian ini dilakukan di SDN Karang Tengah 5 Kota Tangerang. Pendekatan yang digunakan dalam penelitian ini adalah pendekatan kualitatif dengan jenis metode studi kasus. Menurut Sugiono (2016), "Metode penelitian kualitatif adalah metode penelitian yang berlandaskan pada filsafat postpositivisme, digunakan untuk meneliti pada kondisi obyek yang alamiah, (sebagai lawannya adalah eksperimen) dimana peneliti ini adalah sebagai instrumen kunci (h. 9)

Menurut Mawardi (2019), "Penelitian studi kasus pada dasarnya ialah penelitian yang mempelajari secara intensif seseorang individu atau kelompok yang dipandang mengalami kasus tertentu" (h. 43). Dari penjelasan tersebut, dalam penelitian ini peneliti akan mempelajari secara mendalam dan rinci mengenai persoalan atau permasalahan kesulitan belajar anak disgrafia pada mata pelajaran bahasa indonesia di kelas IV SDN Karang Tengah 5 Kota Tangerang.

Jenis data dalam penelitian ini ialah data primer yaitu data yang diperoleh dari penglihatan langsung. dan data sekunder yaitu data yang sudah tersedia di tempat penelitian. Yang menjadi sumber dalam penelitian ini adalah guru kelas IVB, dua orang siswa kelas IVB yang mengalami disgrafia beserta orang tuanya. teknik pengumpulan data dalam penelitian ini dilakukan dengan cara observasi, wawancara dan studi dokumentasi.

Analisis data merupakan proses memilah data dari awal data diperoleh hingga kemudian data disimpulkan dengan tujuan agar data dalam penelitian mudah dipahami dan dimengerti oleh siapa pun yang membacanya. Pada penelitian ini peneliti menggunakan teknik analisis data model Miles \& Huberman, yang meliputi: reduksi data, penyajian data, dan penarikan kesimpulan. Selain itu, agar data yang diperoleh akurat dan absah peneliti juga melakukan pemeriksaan data dengan teknik triangulasi data.

\section{HASIL DAN PEMBAHASAN}

Penelitian dengan judul "Analisis Kesulitan Belajar Anak Disgrafia Pada Mata Pelajaran Bahasa Indonesia Di Kelas IV SDN Karang Tengah 5 Kota Tangerang” merupakan sebuah penelitian yang dilakukan untuk mengetahui kesulitan belajar menulis yang terjadi pada siswa yang mengalami disgrafia saat pembelajaran bahasa indonesia.

Berdasarkan hasil observasi, wawancara, dan studi dokumentasi, peneliti dapat mendiagnosa bahwa kedua siswa yang menjadi subjek penelitian benar-benar mengalami gangguan belajar menulis atau disgrafia. Karena subjek memiliki bentuk tulisan yang tidak konsisten dan proporsional. Dalam tulisannya terdapat huruf-huruf yang terbalik dan ejaan yang tidak tepat karena mereka suka menghilangkan atau menambahkan huruf dalam tulisannya. Kesalahan tersebut tetap mereka lakukan meskipun hanya diminta untuk menyalin tulisan yang sudah ada. Lalu, keduanya juga masih salah dalam menempatkan huruf kapiital.

Kemudian, dari cara menulis salah satu subjek ketika menulis posisi badannya terlalu membungkuk dan pandangan matanya sangat dekat dengan buku. Cara ia memegang pensil pun berbeda dengan siswa lainnya, salah satu 
subjek ketika memegang pensil ia memasukan jari jempolnya ke dalam genggaman. Padahal, beberapa kali guru sudah mencontohkan bagaimana cara menulis dengan baik tapi siswa tetap mengulangi kesalahannya tersebut. Hal itu juga dikarenakan ketika di rumah orang tua mereka membiarkannya. Dengan cara menulis yang seperti itu, sebenarnya menyulitkan siswa sehingga hasil tulisan mereka menjadi sulit terbaca.

Selain itu, kedua subjek saat belajar tidaklah fokus atau konsentrasi sehingga menyebabkan mereka tidak aktif di kelas dan tidak dapat menyampaikan ide atau pengetahuannya ke dalam tulisan. Untuk mengatasi hal tersebut, pada saat belajar guru dan orang tua memberikan reward kepada subjek seperti dengan memberikan tepuk tangan atau kalimat-kalimat pujian. Karena reward tersebut, subjek merasa dihargai dan percaya diri maka dari itu mereka akan termotivasi untuk berkonsentrasi pada saat belajar.

Berdasarkan hasil temuan, yang telah peneliti uraikan tersebut kedua subjek dapat dipastikan mengalami kesulitan belajar menulis atau disgrafia karena kesulitan yang mereka miliki seperti ciri-ciri disgrafia. Menurut Syofiyah (2020), "Bahwa apabila seseorang sudah mengalami gejala-gejala suatu ketidaknormalan paling sedikitnya tiga gejala maka orang tersebut sudah bisa dikatakan telah mengalami ketidaknormalan" (h.42). Dari pendapat tersebut, sudah bisa dipastikan bahwa kedua subjek mengalami kesulitan belajar menulis atau disgrafia karena di dalam diri keduanya terdapat ciriciri disgrafia.

\section{KESIMPULAN DAN SARAN Kesimpulan}

Setelah peneliti menjabarkan data-data yang telah diperoleh selama penelitian dengan judul "Analisis Kesulitan Belajar Anak Disgrafia pada Mata Pelajaran Bahasa Indonesia Di Kelas IV SDN Karang Tengah 5 Kota Tangerang”. Maka peneliti dapat menarik kesimpulan bahwa kesulitan belajar yang dialami oleh siswa yang menjadi subjek penelitian adalah kesulitan belajar menulis atau disgrafia. Hal tersebut dikarenakan ketika menulis mereka memiliki bentuk tulisan yang tidak konsisten dan proporsional. Kemudian, dalam tulisannya terdapat huruf yang terbalik seperti "i" menjadi " $y$ " dan seterusnya. Kemudian dalam tulisan mereka juga terdapat ejaan kata yang tidak tepat hal itu disebabkan karena mereka suka menghilangkan atau menambahkan huruf. Dalam tulisan mereka juga penggunaan huruf besar/ kapital masih tercampur.

Kesalahan-kesalahan mereka saat menulis juga tidak terlepas dari cara menulis mereka yang salah, seperti yang dilakukan oleh salah satu siswa yang menjadi subjek penelitian ia menulis dengan posisi badan yang membungkuk dan pandangan matanya dekat dengan buku serta cara memegang pensil pun berbeda dengan siswa lainnya. Konsentrasi yang mereka miliki juga kurang, karena ketika hanya diminta menulis tulisan yang sudah ada mereka mengalami kesulitan serta mereka tidak dapat menuangkan ide dan pengetahuannya ke dalam tulisan yang sudah ada.

\section{Saran}

Berdasarkan kesimpulan dalam penelitian ini, maka terdapat saran sebagai berikut: 


\section{Untuk Guru}

Sebaiknya guru melakukan upaya atau penanganan lain yang tepat untuk mengatasi siswa yang mengalami kesulitan belajar menulis atau disgrafia apabila dengan cara remedial atau memberi latihan menulis secara terus menerus tidak berhasil. Selain, itu guru juga diharapkan menjalis komunikasi dengan orang tua.

\section{Untuk Orang Tua}

Orang tua diharapkan memberikan perhatian yang lebih kepada anak yang mengalami disgrafia, karena dengan perhatian orang tua anak akan dapat termotivasi dan tidak merasa putus asa untuk menghadapi kesulitan yang dialaminya. Selain, itu orang tua juga diharapkan menjalis komunikasi dengan guru.

\section{Untuk Siswa}

Siswa diharapkan menghilangkan tingkah laku negatif yang dimilikinya, serta terus semangat dan termotivasi saat belajar agar mampu mengikuti kegiatan belajar dengan baik sehingga tujuan pebelajaran dapat tercapai.

\section{DAFTAR PUSTAKA}

Aphroditta. (2013). Panduan Lengkap

Orangtua \& Guru Untuk Anak Dengan Disgrafia (Kesulitan Menulis). Yogyakarta: Javalitera.

Maryani, dkk. (2018). Model Intervensi Gangguan Kesulitan Belajar. Yogyakarta.

Mawardi. (2019). Dasar-dasar Metodologi Penelitian Pendidikan. Yogyakarta: Samudra Biru.

Puspitasari, D \& Rahmawati, D. (2018).

Panduan Pendampingan Gangguan
Belajar Disgrafia. Tangerang: Albasil Aksara.

Rofiqi \& Rosyid, M. Z. (2020). Diagnosis

Kesulitan Belajar Pada Siswa. Malang:

Literasi Nusantara.

Shoffiyah, Hana. (2020). Analisis Kesulitan

Belajar Anak Disgrafia pada

Pembelajaran Bahasa Indonesia Di

Kelas Tinggi Sekolah Dasar. (Disertasi

Sarjana, Universitas Pendidikan Indonesia, 2020). Diakses dari http://repository.upi.edu/52355/

Sugiyono. (2016). Metode Penelitian Kuantitatif, Kualitatif, dan $R \& D$. Bandung: Alfabeta.

Urbayatun, S. (2019). Kesulitan Belajar \& Gangguan Psikologis ringan Pada Anak (Implementasi pada Anak Usia Sekolah Dasar). Yogyakarta: K-Media. 